\title{
PELATIHAN DAN PEMBELAJARAN AKSARA BALI PADA ANAK-ANAK DI PASRAMAN AMERTA SANJIWANI
}

\author{
( Wayan Agus Gunada1), Gede Eka Puja Dyatmika1), ( Gusti Lanang Ngurah Weda') \\ 1)Program Studi Pendidikan Agama Hindu, Jurusan Dharma Acarya, STAHN Gde Pudja Mataram, Mataram, Indonesia \\ Corresponding author : I Wayan Agus Gunada \\ E-mail : gunadastahngpmataram@gmail.com
}

Diterima 16 Februari 2021, Direvisi 26 Februari 2021, Disetujui 27 Februari 2021

\begin{abstract}
ABSTRAK
Tujuan dalam penulisan hasil kegiatan pengabdian masyarakat ini adalah memberikan gambaran terkait kegiatan pelatihan menulis aksara Bali pada anak-anak di Pasraman Amerta Sanjiwani Desa Rincung. Aksara Bali merupakan jenis aksara yang masih berkembang di Pulau Bali yang merupakan bahasa tulis yang umumnya digunakan pada teks-teks suci dalam bentuk lontar. Anak-anak pada Pasraman Amerta Sanjiwani di Desa Rincung Kabupaten Lombok Barat merupakan warga keturunan Bali , secara umum anak-anak mengenal keberadaan aksara Bali namun hanya sebatas visual sehingga pelatihan ini penting dilakukan untuk memberikan pemahaman dan penguatan dalam dasar-dasar menulis aksara Bali dan membaca aksara Bali . Kegiatan pengabdian ini dilakukan dengan menggunakan pendekatan pelatihan dan pembelajaran namun karena dalam keadaan pandemi Covid-19 proses pelatihan tetap mengedepankan pelaksanaan protokol kesehatan. Pengumpulan data dilakukan dengan teknik observasi dan wawancara serta studi dokumentasi selama kegiatan pengabdian kepada masyarakat berlangsung. Secara garis besar dalam proses pelatihan dan pembelajaran anak-anak terlihat antusias dan mulai memahami dasar-dasar bentuk dan penulisan aksara Bali melalui model pendekatan dan pembimbingan secara langsung. Adapun dalam kegiatan pengabdian kepada masyarakat ini dapat memberikan manfaat berupa penambahan wawasan pengetahuan mengenai aksara Bali kepada anakanak dan diharapkan pelatihan dapat dilakukan kemBali untuk penguatan pemahaman tentang aksara Bali .
\end{abstract}

Kata kunci: aksara Bali; pelatihan; anak-anak; agama hindu

\begin{abstract}
The purpose of writing the results of this community service activity is to give an overview of Balinese writing training activities to children in Pasraman Amerta Sanjiwani Rincung Village. Balinese script is a type of script that is still developing on Bali's island, which is a written language commonly used in sacred texts in the form of lontar. The children of Pasraman Amerta Sanjiwani in Rincung Village, West Lombok Regency, are Balinese, who know Balinese characters. However, only visually so this training is essential to understand and strengthen in the basics of writing Balinese characters and reading Balinese characters. This devotional activity is carried out using a training and learning approach, but because of a Covid-19 pandemic, the training process still prioritizes the implementation of health protocols. The data collection is carried out by observation and interview techniques and documentation studies during community service activities. In the training and learning process, the children seem enthusiastic and understand the basics of Balinese form and scriptwriting through a direct approach and mentoring model. Meanwhile, this community service activity can provide benefits in the form of additional knowledge about Balinese script to children, and it is expected that training can be done again to strengthen understanding of Balinese characters.
\end{abstract}

Keywords: Balinese script; training; children; hinduism

\section{PENDAHULUAN}

Pengabdian kepada masyarakat merupakan salah satu unsur yang cukup penting dalam pelaksanaan pengelolaan dan pelaksanaan proses pendidikan di Perguruan Tinggi. Secara sederhana pengabdian kepada masyarakat merupakan proses serta implementasi keilmuan oleh perguruan tinggi yang kemudian diterapkan dalam kehidupan masyarakat. Ini merupakan bentuk kewajiban dari perguruan tinggi dalam mendiseminasikan ilmu pengetahuan sehingga ilmu pengetahuan tidak hanya sekedar memiliki posisi pada tataran teori saja namun lebih penting adalah penerapannya pada tataran praktis. Sehingga 
ilmu pengetahuan dapat berguna untuk kehidupan masyarakat.

Sekolah Tinggi Agama Hindu Negeri Gde Pudja Mataram sebagai salah satu Perguruan Tinggi Keagamaan Hindu Negeri juga memiliki tanggung jawab dalam menyebarluaskan ilmuilmu pengetahuan khususnya dalam bidang keagamaan Hindu dalam rangka ikut serta berperan aktif membangun sumber daya umat Hindu yang berkarakter melalui kegiatan pengabdian kepada masyarakat. Sehingga tujuan lembaga sebagai pusat kajian agama Hindu yang unggul dan berdaya saing dapat tercapai melalui penerapan-penerapan keilmuan agama di masyarakat sehingga terbentuknya pemahaman masyarakat yang komprehensif mengenai esensi agama Hindu yang tidak hanya pada tataran ritus yadnya semata namun juga penguatan pemahaman mengenai tattwa dan susila. Sehingga dapat membentuk umat Hindu yang berkarakter dalam rangka ikut membangun sumber daya manusia yang menunjang proses pembangunan bangsa dan negara yang maju.

Salah satu kegiatan pengabdian kepada masyarakat yang telah berlangsung dan selesai dilaksanakan oleh lembaga melalui Program Studi Pendidikan Agama Hindu adalah kegiatan pelatihan dan pembelajaran aksara Bali pada anak-anak di desa Rincung Kabupaten Lombok Barat tepatnya pada Pasraman Amerta Sanjiwani. Dilihat dari demografis kependudukan maka sebagian besar masyarakat merupakan warga keturunan Bali yang telah tinggal sejak lama di Pulau Lombok dan beragama Hindu.

Aksara Bali merupakan salah satu jenis aksara yang masih berkembang di Bali yang umumnya sekarang lebih banyak ditemukan pada teks-teks suci yang berbentuk lontar namun melalui upaya-upaya pelestarian maka kini aksara Bali sudah mulai mendapat perhatian khusus terlihat dari berbagai bentuk visual aksara Bali yang diwajibkan digunakan pada papan-papan identitas lembaga baik negeri maupun swasta di Bali. Dalam prosesnya pula aksara Bali tidak hanya sekedar bahasa teks tulis namun dalam realitanya penggunaan aksara Bali terbagi atas dua klasifikasi yaitu aksara untuk penggunaan teks biasa berupa aksara Bali wreastra dan swalalita dan aksara Bali yang umumnya digunakan pada ritus-ritus keagamaan suci berupa aksara wijaksara dan modre (Rai, 2013).

Penggunaan aksara Bali dan bahasa Bali dikalangan anak muda kini rasanya telah mulai terjadi penurunan minat karena dianggap susah dan cenderung kuno sehingga peminatnya mulai berkurang. Ini tentu menjadi suatu permasalahan dimana aksara Bali sebagai bagian dari bahasa Bali malah kini mendapat porsi dan perhatian yang kurang dari penggunanya, digeser oleh bahasa-bahasa yang dianggap modern. Ini tentu disebabkan karena berbagai faktor sehingga minat pengguna bahasa Bali mulai berkurang tidak hanya dikalangan remaja, bahkan elit sebagai individu yang menjadi panutan kurang menggunakan bahasa Bali sebagai bahasa komunikasi, disamping juga dikarenakan faktorfaktor perkembangan zaman yang cukup mempengaruhi bergesernya fungsi bahasa Bali sebagai bahasa keseharian masyarakat Bali (Sudiarta, 2016).

Hal-hal ini lah yang kemudian membuat Program Studi Pendidikan Agama Hindu merancang suatu kegiatan pelatihan dan pembelajaran aksara Bali bukan hanya sebagai bentuk implementasi keilmuan namun sebagai upaya dalam mendukung dan melestarikan bahasa Bali khususnya aksara Bali sebagai bahasa 'Ibu' disamping itu pula untuk menunjang keberhasilan dalam misi program studi untuk mengimplementasikan nilai-nilai pendidikan agama Hindu di masyarakat.

Pemilihan kegiatan pelatihan dan pembelajaran aksara Bali pada anak-anak bertujuan untuk melatih dan memberikan pemahaman baik teori dan praktik sehingga anak-anak mampu untuk mengetahui secara visual bentuk dari aksara Bali, dasar membaca dan menulis aksara Bali. Ini dikarenakan anakanak sebagai penerus umat Hindu untuk dapat terus mengembangkan pemahaman keilmuan keagamaan Hindu yang umumnya ajaranajaran sucinya tidak hanya ditulis pada kitabkitab suci yang sudah diterjemahkan dengan huruf latin, namun juga banyak ajaran-ajaran suci Hindu yang tertulis dalam lontar-lontar yang menggunakan aksara Bali. Ini kemudian ditegaskan bahwa keberadaan aksara Bali yang umum ditemukan dalam Iontar-lontar sangat berperan penting dalam setiap ritus keagamaan Hindu karena dalam setiap upacara keagamaan selalu ditemukan aksara Bali sebagai bagian dari pelaksanaan upacara (Parsua, 2018).

Secara makna kata istilah aksara Bali merujuk kepada sistem bahasa teks yang menggunakan simbol-simbol visual berupa tulisan dan gambar (Setiyawan, Cahyawan W, \& Bayupati, 2014). Ini memberikan kesimpulan bahwa aksara Bali merupakan sistem bahasa teks yang menggunakan simbol-simbol visual, bahasa teks ini lebih sering dijumpai dalam sastra-sastra tradisional yang mengandung nilai-nilai ajaran Hindu. Dengan diadakannya pengabdian kepada masyarakat melalui kegiatan pelatihan dan pembelajaran aksara Bali ini diharapkan anak-anak pada Pasraman 
Amerta Sanjiwani dapat memahami keberadaan aksara Bali sebagai bahasa Ibu dan warisan leluhur sehingga mampu untuk mengembangkan dan melestarikannya serta dapat digunakan untuk membaca teks-teks suci Hindu baik sebagai penguatan pemahaman ajaran agama Hindu dan penguatan pendidikan karakter melalui internalisasi nilai ajaran agama Hindu.

Berdasarkan latar belakang diatas terkait dengan pelatihan dan pembelajaran aksara Bali maka ditemukan beberapa pustaka yang relevan dan menunjang dalam kegiatan pelatihan aksara Bali ini. Giri (2017) menyebutkan bahwa bahasa Bali dan aksara Bali merupakan suatu unsur kebudayaan Bali yang cukup penting keberadaannya baik difungsikan sebagai bahasa komunikasi ataupun sebagai media dalam ritus keagamaan Hindu, mulai berkurangnya peranan bahasa Bali sebagai bahasa komunikasi tentu harus mendapat perhatian agar bahasa dan aksara Bali tidak hilang. Oleh karenanya dalam upaya untuk tetap melestarikan bahasa Bali maka lembaga keluarga, masyarakat dan sekolah harus berperan dalam usaha pelestarian bahasa dan aksara Bali (Giri, 2017).

Aksara Bali tidak hanya ditemukan pada teks-teks dalam lontar namun juga ditemukan pada sarana-sarana upakara keagamaan Hindu salah satunya pis bolong. Pis bolong khususnya dalam daksina memiliki makna sebagai simbol dan lambang dari windu yang berarti ketiadaan, kekosongan dan kesucian dan merupakan lambang panca dewata yang diharapkan dapat menghadirkan Tuhan dalam prosesinya. Pis bolong juga berfungsi sebagai sarana untuk menghubungkan diri kepada Tuhan dan terkandung nilai-nilai serta ajaran suci Hindu di dalamnya (Merthawan, 2017).

Pelestarian dan pengembangan bahasa dan aksara Bali tentu mendapat perhatian yang cukup penting mengingat bahasa merupakan bagian dari kebudayaan khususnya budaya Bali. Sehingga dalam upayanya terdapat beberapa hal yang dapat dilakukan untuk menjaga eksistensi keberadaanya diantaranya pengadaan kegiatan pasraman sebagai wadah pendidikan keagamaan Hindu, lomba-lomba yang memfokuskan pada penggunaan bahasa dan aksara Bali, serta meningkatkan lagi peran masyarakat, keluarga dan sekolah serta pemerintah dalam penggunaan bahasa Bali (Sudiarta, 2016).

Perkembangan aksara Bali dan usaha pelestariannya tentu harus dilakukan melalui beragam upaya. Mulai turunnya minat masyarakat khususnya dikalangan remaja dan anak-anak dalam mempelajari bahasa Bali tentu harus mendapat perhatian sehingga salah satu hal yang dapat dilakukan adalah mentransformasi media pembelajaran aksara Bali dengan mengadaptasi teknologi dalam prosesnya. Salah satunya adalah dengan sistem game yang dapat digunakan dan dipasang pada device android, dengan berbagai tampilan serta aspek-aspek entertainment dan edukasi di dalamnya akan sangat mendukung dalam memberikan motivasi untuk pembelajaran aksara Bali sebagai salah satu upaya dalam melestarikan aksara Bali sebagai bagian dari kebudayaan Bali (Setiyawan et al., 2014).

Berdasarkan beberapa pustaka diatas yang relevan dalam kegiatan pelatihan dan pengabdian kepada masyarakat ini maka dapat disimpulkan bahwa aksara Bali memiliki fungsi dan posisi yang sangat penting dalam kehidupan kebudayaan Bali. Tidak hanya sebagai sistem bahasa dalam fungsinya sebagai bahasa komunikasi sehari-hari, aksara Bali juga merupakan bagian dari media dan sarana yang digunakan dalam upacara yadnya dalam ritus keagamaan Hindu. Aksara-aksara Bali ini ditemukan baik dalam lontar-lontar, maupun ditulis dan digambar pada mediamedia keagamaan seperti kajang, ulap-ulap dan rerajahan. Perkembangan zaman dewasa kini, juga sangat mempengaruhi keberadaan bahasa Bali dimana posisinya bergeser oleh bahasa-bahasa yang modern sehingga membuat penuturnya berkurang. Tentu hal ini harus mendapat perhatian dengan berbagai upaya-upaya salah satunya mengadaptasi teknologi sebagai media pembelajaran untuk menunjang usaha pelestarian aksara Bali .

Berkaitan dengan hal tersebut maka pustaka terdahulu berperan penting dalam menguatkan pemahaman dan teori dalam kegiatan pelatihan dan pembelajaran aksara Bali ini namun penelitian dan kegiatan ini memiliki perbedaan salah satunya adalah pada lokasi penelitian pada Pasraman Amerta Sanjiwani di Desa Rincung Kabupaten Lombok Barat yang tentu memiliki tantangan yang berbeda dengan Bali sebagai daerah asli bahasa dan aksara Bali berkembang. Sehingga perbedaan lokasi ini tentu akan memberikan hasil serta metode yang berbeda sehingga memberikan kebaruan dalam prosesnya.

Secara pragmatis penulisan kegiatan pengabdian kepada masyarakat ini berguna untuk memberikan gambaran bagaimana proses pelaksanaan pelatihan dan pembelajaran aksara Bali pada anak-anak di Pasraman Amerta Sanjiwani dilakukan. Pelatihan ini bertujuan untuk mengimplementasikan nilai-nilai ajaran agama Hindu melalui proses pendidikan sehingga ajaran agama Hindu tidak hanya pada tataran 
teori namun juga diterapkan dalam kehidupan nyata. Serta dapat memberikan manfaat dalam menguatkan pemahaman dan pengetahuan anak-anak mengenai warisan budayanya yaitu aksara Bali sebagai bahasa ibu sehingga dapat dipelajari dan berdampak pada anak-anak agar dapat membaca teks-teks ber-aksara Bali dan menulis aksara Bali. Penulisan ini juga bermanfaat untuk menambah wawasan dan pengetahuan mengenai perkembangan aksara Bali pada daerah-daerah umat Hindu tinggal diluar Bali sehingga dapat menjadi kajian kritis mengenai usaha-usaha pelestarian aksara Bali di masa depan.

\section{METODE}

Pelaksanaan kegiatan pengabdian kepada masyarakat ini dilakukan dengan menggunakan dua metode yaitu metode pelaksanaan kegiatan dan metode penelitian yakni pengumpulan data. Dalam situasi masa pandemi covid-19 ini maka proses kegiatan pengabdian kepada masyarakat sangat ditekankan dengan disiplin menjalankan protokol kesehatan sehingga sasaran pengabdian kepada masyarakat adalah komunitas umat Hindu yang berlokasi pada Pasraman Amerta Sanjiwani di Desa Rincung Kabupaten Lombok Barat sebagai wadah pendidikan keagamaan Hindu nonformal.

Kegiatan Pengabdian Kepada Masyarakat dilakukan pada Hari Minggu tanggal 20 September 2020 dengan jumlah peserta pelatihan dan pembelajaran sebanyak 14 orang anak-anak yang merupakan sisya atau peserta didik pada Pasraman Amerta Sanjiwani yang berusia sekitar 8-10 tahun. Proses pelaksanaan kegiatan pelatihan aksara Bali ini melibatkan dosen dan perwakilan mahasiswa pada program studi Pendidikan Agama Hindu bekerja sama dengan pengelola Pasraman Amerta Sanjiwani.

Metode pelaksanaan kegiatan pengabdian kepada masyarakat dilakukan dengan model pelatihan dan pembelajaran secara terstruktur. Maksudnya adalah pelatihan dilakukan dengan merancang proses kegiatan dengan matang. Istilah pelatihan mengacu kepada internalisasi materi dan keahlian. Pelatihan pada prosesnya menitik beratkan materi dan keterampilan sehingga sasaran pelatihan dapat meningkatkan keahliannya pada bidang yang diinginkan (Nurhayati, 2018).

Sedangkan pembelajaran mengacu kepada konsep proses transfer pengetahuan kepada peserta didik. Istilah pembelajaran mengacu dimana dalam prosesnya terjadi interaksi antara pendidik dengan peserta didik dalam suatu suasana dan lingkungan belajar (Pane \& Darwis Dasopang, 2017). Pada
Gambar 1. merupakan alur pelaksanaan kegiatan Pelatihan dan Pembelajaran aksara Bali dan dapat disimpulkan bahwa dalam kegiatan ini maka pelatihan dan pembelajaran aksara Bali memiliki makna kegiatan internalisasi dan penguatan materi dan konsepsi aksara Bali melalui proses transfer dan transformasi keilmuan aksara Bali untuk memperkuat keahlian bagi anak-anak pada pasraman Amerta Sanjiwani dalam membaca dan menulis aksara Bali dasar.

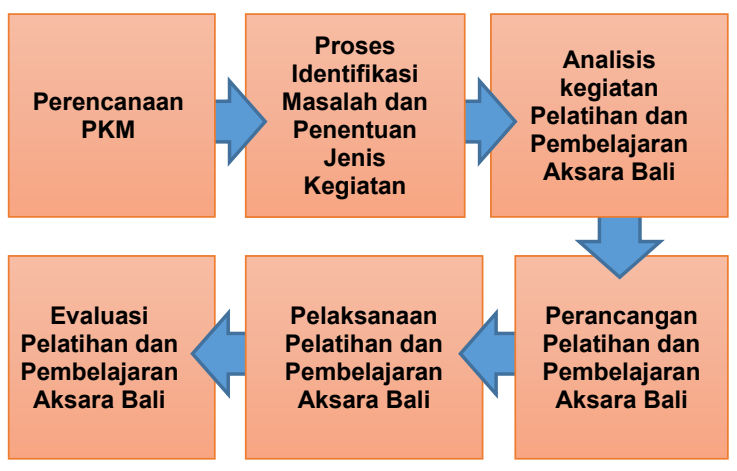

Gambar 1. Alur Pelaksanaan Kegiatan Pelatihan dan Pembelajaran Aksara Bali

Metode pengumpulan data dilakukan melalui proses observasi, diskusi dan studi dokumentasi. Proses pengamatan dilakukan sebelum kegiatan dilakukan untuk melihat situasi lingkungan dan suasana belajar pada Pasraman Amerta Sanjiwani untuk melihat model kegiatan pengabdian kepada masyarakat yang dilakukan dan kegiatan pengamatan selama pelatihan dan pembelajaran aksara Bali dilaksanakan. Data kemudian dianalisis menggunakan model Miles Huberman, model Miles dan Huberman menggunakan tiga tahapan kegiatan yaitu reduksi data dimana data diproses melalui pemilahan data, penyajian data yaitu proses mempolakan data pada konsep-konsep yang berhubungan dengan permasalahan dan verivikasi data yaitu menarik kesimpulan dan menginterpretasi data (Sugiyono, 2020).

\section{HASIL DAN PEMBAHASAN}

Berdasarkan hasil analisa terkait kegiatan pelatihan dan pembelajaran penguatan materi dasar pengenalan cara membaca dan menulis aksara Bali kepada anak-anak peserta didik di pasraman Amerta Sanjiwani maka dapat dijelaskan sebagai berikut :

\section{Perencanaan Pelatihan dan Pembelajaran dasar-dasar aksara Bali. \\ Pada kegiatan pelatihan dan} pembelajaran aksara Bali berupa materi dasar 
dan pengenalan bentuk serta cara membaca dan menulis aksara Bali maka dilakukan proses perencanaan berupa rancangan desain bentuk pelatihan dan pembelajaran yang akan dilakukan. Proses perencanaan ini tentu memiliki tujuan agar kegiatan yang dilakukan dapat berjalan dengan efektif dan efisien mengingat kondisi dan situasi pada saat kegiatan pengabdian kepada masyarakat ini dilakukan saat masa Pandemi Covid-19.

Karena situasi pandemi yang tidak hanya dirasakan di Indonesia saja namun melanda secara global maka kebijakan-kebijakan yang diambil untuk memutus rantai penyebaran dan penularan covid-19 diambil oleh pemerintah diantaranya social distansing, jaga jarak, kemudian bekerja dari rumah dengan istilah WFH, serta meliburkan proses pembelajaran di Lembaga Sekolah dan Perguruan tinggi melalui pembelajaran daring. Kebijakan ini diambil sebagai upaya dalam meminimalisir penyebaran dan penularan virus Covid-19 (Agustino, 2020). Oleh karenanya dalam proses pelaksanaan kegiatan pengabdian kepada masyarakat ini maka benar-benar dirancang dan direncanakan dengan tetap memperhatikan protokol kesehatan Covid-19 namun tetap juga mempertimbangkan efisiensi waktu dan efektifitas kegiatan sehingga pelatihan dan pembelajaran aksara Bali sebagai bentuk implementasi keilmuan dan nilai-nilai pendidikan agama Hindu dapat dilaksanakan. Proses perancangan kegiatan pelatihan dan pembelajaran ini kemudian memperhatikan prinsip perancangan desain pembelajaran.

Berdasarkan hal tersebut maka kegiatan pelatihan dan pembelajaran dasar-dasar menulis dan membaca aksara Bali dengan menekankan kepada model desain pembelajaran berbasis atau berorientasi pada kelas. Desain pembelajaran ini merupakan salah satu model pembelajaran yang dikembangkan untuk mendukung pendidik dalam proses belajar mengajar yang mendasarkan prosesnya pada interaksi pendidik dengan peserta didik pada kurun waktu tertentu pada suatu lingkungan kelas (Setyosari, 2020).

Model pelatihan dan pembelajaran berorientasi kelas ini oleh Heinich, dkk (1999) dalam Setyosari (2020) ditekankan pada beberapa tahapan diantaranya menganalisis siswa, merumuskan tujuan pembelajaran, pemilihan media, penggunaan media, membentuk partisipasi siswa dan mengevaluasi proses kegiatan pelatihan dan pembelajaran yang dilakukan (Setyosari, 2020).

Dari enam proses dan tahapan tersebut maka dapat diuraikan sebagai berikut :

\section{Proses Analisa Siswa.}

Dari hasil pengamatan dan survey pada Pasraman Amerta Sanjiwani didapatkan informasi bahwa sebagian besar sisya atau peserta didik merupakan anak-anak pada jenjang sekolah dasar yang umumnya berusia 8-10 tahun dan sisanya merupakan anak-anak remaja yang aktif dalam proses belajar mengajar untuk peningkatan pemahaman ajaran agama Hindu.

Anak-anak pada usia sekitar 8-10 tahun merupakan usia anak sekolah yang sudah mendapatkan proses peningkatan intelektual dimana pada masa ini anak-anak sudah dapat membaca, menulis dan berhitung. Dilihat dari sisi perkembangan emosional maka anak-anak sudah memahami terkait bagaimana berekspresi. Kemudian jika dilihat dari aspek perkembangan sosial maka anak-anak sudah mampu membangun interaksi sosial berupa kerjasama antara teman sebaya dan lingkungan masyarakatnya, pada perkembangan ini pula anak-anak mulai membangun eksistensi diri melalui prestasiprestasi yang ditunjukkan (Yusuf L.N \& Sugandhi, 2013).

Berdasarkan hal tersebut melalui pengamatan situasi dan kondisi lingkungan belajar pada pasraman maka dalam pelatihan dan pembelajaran ini, peserta difokuskan kepada peserta didik pada pasraman amerta sanjiwani yang merupakan anak usia sekolah. Melihat perkembangan sosio-emosional dan jenjang pendidikan anak, maka anak-anak peserta didik pada pasraman sudah mampu untuk membaca, menulis dan berhitung tingkat dasar, sudah mampu untuk berinteraksi baik kepada teman-teman sebayanya dan berinteraksi kepada lingkungan masyarakat.

Pada proses pengamatan pula, anakanak ini masih pada tahap bermain sehingga harus dipilih strategi dan media serta materi pembelajaran yang menyenangkan, sehingga mampu beradaptasi pada sisi sosio-emosional anak dan tetap mampu memberikan transfer pengetahuan khususnya materi dasar mengenal cara menulis dan membaca aksara Bali .

\section{Perumusan Tujuan Kegiatan Pelatihan dan Pembelajaran Aksara Bali.}

Dalam proses merancang suatu model dan desain pelatihan serta pembelajaran maka hal yang harus dipertimbangkan adalah apa hasil yang diharapkan terjadi selama dan setelah proses pelatihan dan pembelajaran dilakukan dengan istilah sederhananya adalah tujuan pembelajaran. Langkah ini menekankan 
kepada hasil apa yang diharapkan terjadi dalam proses pembelajaran (Setyosari, 2020).

Sehingga dalam proses pelatihan dan pembelajaran aksara Bali ini melihat situasi serta lingkungan belajar siswa pada usia 8-10 tahun hanya pada dasar-dasar serta pengenalan bentuk visual aksara Bali serta cara untuk menulis dan membaca aksara Bali secara mendasar, melalui pembentukan Taksonomi pembelajaran yaitu sisi pengetahuan, sikap dan keterampilannya. Isitilah taksonomi mengacu kepada pemahaman adanya proses hierarki yang bertujuan untuk mengorganisasian proses pembelajaran melalui perumusan tujuan pembelajaran, salah satu taksonomi yang umum dipergunakan adalah taksonomi Bloom pada aspek kognitif yaitu pengetahuan, pemahaman, penerapan, analisis, evaluasi dan mengkreasikan (Gunawan \& Palupi, 2012).

Jika mengacu kepada materi yang akan diberikan dan melihat sasaran peserta didik maka konteks aksara Bali yang diinternalisasi adalah dasar-dasarnya saja. Sehingga sesuai dengan ranah taksonomi Bloom maka proses pelatihan dan pembelaran aksara Bali ini hanya menekankan dari C-1 sampai Dengan C-3 yaitu pada aspek pengetahuan, pemahaman dan aplikasi atau penerapannya

Adapun tujuan instruksional umum dalam proses pelatihan dan pembelajaran aksara Bali pada anak-anak peserta didik di pasraman Amerta Sanjiwani adalah 1) C-1 aspek pengetahuan yaitu peserta didik mampu menyebutkan klasifikasi aksara Bali berdasarkan bentuk-bentuk visual aksaranya, 2) C-2 aspek pemahaman yaitu peserta didik mampu untuk menjelaskan proses pembentukan aksara Bali , 3) C-3 aspek aplikasi yaitu peserta didik mampu untuk menyesuaikan bentuk aksara Bali sesuai dengan dasar-dasar bentuk dan tata cara penulisan aksara Bali .

\section{Pemilihan media dan bahan ajar aksara Bali}

Proses selanjutnya dalam mendesain dan mengkonsepkan pelatihan dan pembelajaran dasar-dasar aksara Bali pada anak-anak Pasraman Amerta Sanjiwani adalah dengan menggunakan media buku yang umum digunakan dalam pembelajaran aksara Bali Dasar. Selain buku maka dibuatlah lembar kerja seperti yang terlihat pada Gambar 2. yang berisikan contoh-contoh aksara Bali yang kemudian dapat diulang kembali penulisannya oleh peserta didik.

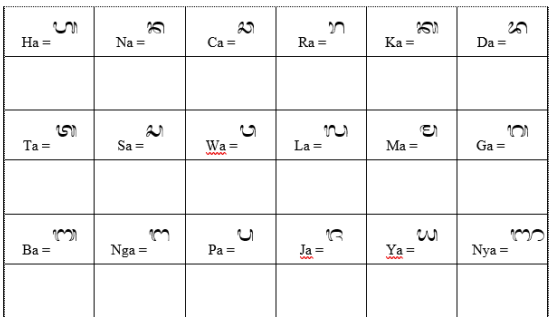

Gambar 2. Lembar Kerja Media Belajar Aksara Bali (Sumber: I Wayan Agus Gunada)

Penggunaan media dan bahan ajar aksara Bali

Media buku dan lembar kerja dirancang untuk digunakan melalui proses pembimbingan secara langsung dimana pelatih langsung memberikan materi secara verbal kepada peserta didik dengan memberikan contoh langsung kepada peserta didik pada papan tulis yang sudah disediakan oleh pengelola Pasraman Amerta Sanjiwani. Adapun materi yang akan diberikan adalah sebagai berikut yang dikutip dalam Suwija (2014) dan beberapa sumber sebagai berikut :

Aksara Bali merupakan salah satu bentuk visual atau simbol bahasa tradisional dalam bahasa Bali yang masih berkembang dan hidup di Bali. Penggunaan bahasa Bali dalam kehidupan masyarakat Bali umunya digunakan untuk menulis teks-teks baik teks yang bersifat biasa menggunakan bahasa sehari-hari yang umumnya menggunakan jenis aksara Wreastra dan Swalalita dan teks yang bersifat suci yang umumnya dipergunakan berkaitan dengan ritus-ritus keagamaan dengan menggunakan aksara Modre dan aksara wijaksara (Rai, 2013).

\begin{tabular}{|c|c|c|c|c|c|}
\hline No & $\begin{array}{l}\text { Huruf } \\
\text { Latin }\end{array}$ & $\begin{array}{c}\text { Aksara } \\
\text { Bali }\end{array}$ & No & $\begin{array}{l}\text { Huruf } \\
\text { Latin }\end{array}$ & $\begin{array}{c}\text { Aksara } \\
\text { Bali }\end{array}$ \\
\hline 1 & ha & $u n$ & 10 & la & nu \\
\hline 2 & na & ร) & 11 & $\mathrm{ma}$ & हा) \\
\hline 3 & $\mathrm{ca}$ & 20 & 12 & ga & $(2)$ \\
\hline 4 & ra & n & 13 & ba & $m$ \\
\hline 5 & ka & 280 & 14 & nga & $m$ \\
\hline 6 & da & 28 & 15 & pa & $U$ \\
\hline 7 & ta & जi & 16 & ja & $\mathbb{R}$ \\
\hline 8 & sa & 21 & 17 & ya & us \\
\hline 9 & wa & ט & 18 & nya & $m$ \\
\hline
\end{tabular}

Gambar 3. Aksara Wreastra

Pada Gambar 3. menunjukkan bentuk Aksara Bali dari sisi bentuk, aksara atau simbol hurufnya terbagi dalam beberapa jenis yang 
pertama adalah aksara Wreastra yang berjumlah 18 aksara yang umumnya digunakan untuk menulis bahasa Bali biasa yaitu ha, na, ca, ra, ka, da, ta, sa, wa, la, ma, ga, ba, nga, pa, ja, ya, nya. Dalam penulisan aksara Bali dalam teks-teks tulis berbeda dengan penulisan menggunakan huruf latin, jika huruf latin yang ditulis adalah kata-kata namun dalam aksara Bali yang ditulis adalah pelafalannya karena lafal bahasa dan sistem bahasa masyarakat Bali memiliki kekhususannya.

Selain itu untuk membentuk kata dalam aksara Bali maka harus diberikan huruf vokal karena aksara wreastra tersebut masih bersifat huruf konsonan. Huruf vokal sebagai pembentuk kata ini disebut dengan pengangge aksara yang berfungsi sebagai atribut untuk membentuk kata-kata yang diharapkan (Suwija, 2014).

Proses untuk membentuk kata tersebut maka huruf wreastra kemudian dipasangkan dengan pengangge suara terlihat seperti pada Gambar 4. sehingga akan membentuk kata baru. Misalkan ketika membentuk kata kakak laki-laki dimana dalam bahasa Bali kata kakak laki-laki adalah 'beli' maka aksara 'ba' yaitu $\mathrm{b}$ ditambahkan dengan pengangge suara 'pepet' yaitu ${ }^{\cdots \cdot . \cdot}$ ) ${ }^{\cdots \cdot}$ dan aksara 'la' yaitu I ditambah pengangge aksara 'ulu' yaitu ${ }^{\cdots \cdot . . . . . . . ' ~ m e n j a d i ~}$ 'beli' b) $\mid \varnothing . .$.

\begin{tabular}{|c|c|c|c|}
\hline No & Bentuk & Nama & Berbunyi \\
\hline 1 & …211 & Tedong & a \\
\hline 2 & $\cdots \cdots 11$ & Ulu & i \\
\hline 3 & $\cdots$ & Suku & u \\
\hline 4 & $\eta \cdots 11$ & Taléng & é \\
\hline 5 & $\eta \cdots \cdot 11$ & Taléng-Tedong & 0 \\
\hline 6 & $\stackrel{\ominus}{*} \|$ & Pepet & e \\
\hline
\end{tabular}

Gambar 4. Pengangge Suara

Dalam penulisan aksara Bali juga terdapat aturan-aturan khusus yang umum digunakan baik menulis aksara Bali secara langsung dalam bahasa Bali ataupun menyalin bahasa dan serapan bahasa di luar Bali seperti bahasa kawi, sanskerta, indonesia dan lain-lain yang disebut dengan uger-uger pasang aksara Bali . Namun melihat rentang usia anak-anak yang masih terbilang kecil maka dalam pelatihan ini materi hanya diberikan dasar saja yaitu pengenalan bentuk, cara membaca dan membentuk aksara wreastra dengan pengangge suara menjadi kata-kata sederhana.
Membangun partisipasi siswa melalui pemilihan strategi pembelajaran.

Pelatihan dan pembelajaran dasar-dasar aksara Bali ini pada anak-anak di pasraman Amerta Sanjiwani dilakukan dengan proses yang matang karena proses kegiatan yang akan dilaksanakan dalam situasi pandemi maka dalam pelatihan dan pembelajaran aksara Bali tentu harus memilih strategi yang tepat disamping memilih metode yang efektif dan efisien juga tetap harus memperhatikan protokol kesehatan covid-19 sebagai upaya dalam berperan serta meminimalisir penyebaran dan penularan virus covid- 19 .

Oleh karenanya pemilihan strategi ini cukup penting dengan melihat situasi, lingkungan dan kondisi belajar pada Pasraman Amerta Sanjiwani. Jenis strategi pelatihan dan pembelajaran yang dipergunakan adalah model strategi pembelajaran ekspositori. Yaitu proses atau strategi pembelajaran dimana pendidik menjadi pusat dari proses pembelajaran yang menekankan penyampaian materi melalui metode ceramah. Dalam prosesnya penyampaian materi dilakukan melalui verbal yang disampaikan oleh pendidik kepada peserta didik dengan menguraikan secara sistematis materi yang disampaikan (Fatimah \& Kartikasari, 2018). Lebih dalam model ekspositori ini melalui penyampaian materi yang disampaikan secara verbal melalui penyampaian lisan oleh pendidik (Randa, Lumbantoruan, \& Putra, 2018).

Pemilihan strategi pembelajaran ekspositori ini dikarenakan situasi dan kondisi pandemi yang mengharuskan proses kegiatan tidak berjalan maksimal, sehingga strategi pembelajaran ini menjadi salah satu strategi pembelajaran yang dapat dilakukan mengingat harus adanya pembatasan jarak fisik, penggunaan daring juga belum memungkinkan karena terbatasnya akses fasilitas yang dimiliki oleh peserta didik.

Sehingga dapat disimpulkan bahwa strategi yang digunakan adalah model ekspositori melalui penyampaian materi dasardasar aksara Bali oleh pendidik dengan proses verbal atau ceramah kepada peserta didik dengan tetap memperhatikan protokol kesehatan.

Evaluasi proses pelatihan dan pembelajaran. Istilah evaluasi merujuk kepada pemahaman penilaian yang dilakukan terhadap suatu kerja dalam hal ini pembelajaran. Dalam kegiatan pelatihan dan pembelajaran ini evaluasi dilakukan dengan mengamati secara langsung peserta didik dalam proses penguatan materi dasar-dasar aksara Bali. Indikator keberhasilan dilihat dari sejauh mana 
peserta didik mampu membedakan bentuk aksara kemudian mencoba menuliskannya pada lembar kerja. Kemudian indikator keberhasilan lainnya adalah ketika peserta didik sedikit-tidaknya sudah mampu membuat kata-kata sederhana dengan menggabungkan aksara wreastra dengan pengangge aksara. Indikator terakhir adalah peserta didik mampu untuk membaca kata-kata sederhana dalam aksara Bali .

\section{Pelaksanaan Pelatihan dan Pembelajaran} dasar-dasar aksara Bali

Kegiatan utama setelah perancangan desain dan konsepsi pelatihan serta pembelajaran aksara Bali dalam pengabdian kepada masyarakat ini adalah proses penerapan desain yang sudah dirancang. Kegiatan pertama yang dilakukan adalah mengucapkan salam kepada peserta didik kemudian melaksanakan perkenalan sebagai bentuk pembangunan interaksi antara pendidik selaku pelatih dan beberapa pendamping yang akan memberikan materi dasar aksara Bali dengan peserta didik yang akan menerima materi aksara Bali .

Kegiatan kedua seperti pada Gambar 5. yang dilakukan adalah melaksanakan apersepsi sebagai pemicu pengetahuan untuk melihat sejauh mana peserta didik atau anakanak pada pasraman amerta sanjiwani memahami keberadaan aksara Bali. Apersepsi secara makna istilah memiliki pengertian sebagai proses pengawalan materi dengan memberikan penguatan-penguatan kecil sehingga terjadi pembentukan minat dalam diri peserta didik untuk siap menerima materi dan apersepsi juga berguna untuk mengingat materi-materi terdahulu (Al-Muwattho, Aminuyati, \& Okianna, 2018).

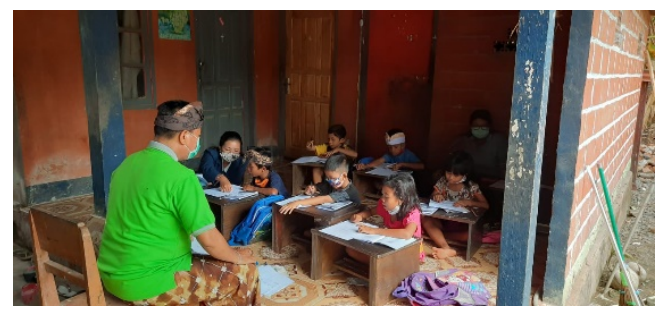

Gambar 5. Pemberian apersepi materi aksara Bali (Sumber: I Wayan Agus Gunada)

Maka dalam pelatihan ini apersepsi berperan untuk memberikan penguatan awal kepada peserta didik mengenai penjelasan secara singkat apa itu aksara Bali sehingga peserta didik siap dengan materi yang akan diberikan. Apersepsi ini juga bertujuan untuk membangun situasi dan kondisi lingkungan belajar sehingga peserta didik mengetahui dan memahami materi apa yang akan diajarkan oleh pelatih.

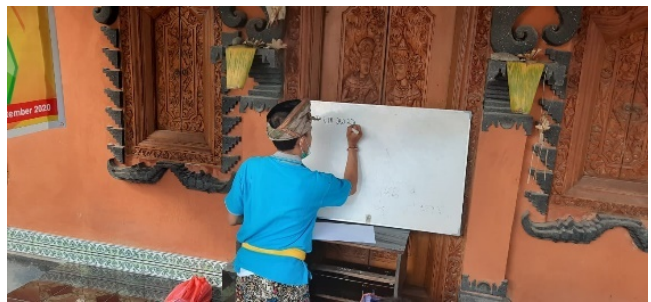

Gambar 6. Pemberian Materi Aksara Bali (Sumber: I Wayan Agus Gunada)

Kegiatan ketiga yang dilaksanakan adalah pemberian penjelasan seperti yang terlihat pada Gambar 6. tujuan dari kegiatan pelatihan dan pembelajaran aksara Bali ini sehingga peserta didik memahami hasil akhir yang diharapkan setelah kegiatan berlangsung dan pemberian materi oleh pelatih atau pendidik. Materi diberikan berupa penjelasan mengenai struktur dan klasifikasi bentuk aksara Bali Wreastra yang berjumlah delapan belas aksara dan penjelasan mengenai pembentukan kata melalui penambahan pengangge aksara.

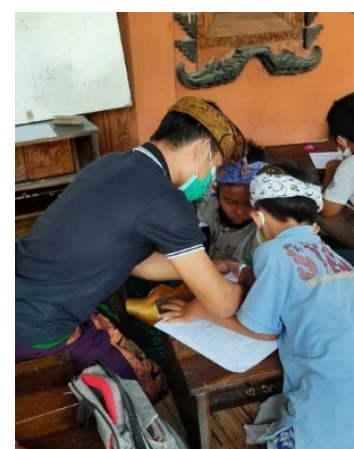

Gambar 7. Pembimbingan teknik menulis aksara Bali oleh Pendamping (Sumber: I Wayan Agus Gunada)

Gambar 7. merupakan kegiatan selanjutnya berupa pembimbingan secara langsung mengenai tata cara penulisan bentuk aksara Bali oleh para pembimbing dan pendamping dalam kegiatan ini. Pembimbingan secara langsung ini bertujuan untuk mendampingi para peserta didik untuk lebih memahami cara menulis aksara Bali sesuai bentuk dan contoh yang telah disediakan, pendampingan juga berfungsi untuk memberikan penguatan terkait proses pembentukan huruf dan pembentukan kata, juga berfungsi secara langsung untuk memberikan koreksi jika terjadi kesalahan bentuk aksara Bali yang ditulis oleh peserta didik. Setelah proses pembentukan huruf dan kata, maka pendamping ini kemudian memberikan teknik cara membaca aksara Bali 
dengan kata-kata sederhana yang mudah untuk dipahami oleh peserta didik.

Pada Gambar 8. merupakan proses terakhir yaitu penilaian sejauh mana peserta didik memahami cara menulis bentuk-bentuk aksara Bali, cara menggabungkan aksara wreastra dengan pengangge aksara dan membaca aksara Bali secara sederhana. proses ini dilakukan langsung oleh pendamping melalui pengamatan secara langsung, sehingga pendamping dapat melihat apakah peserta didik sudah memahami dan mengetahui dasar-dasar dalam menulis dan membaca aksara Bali .

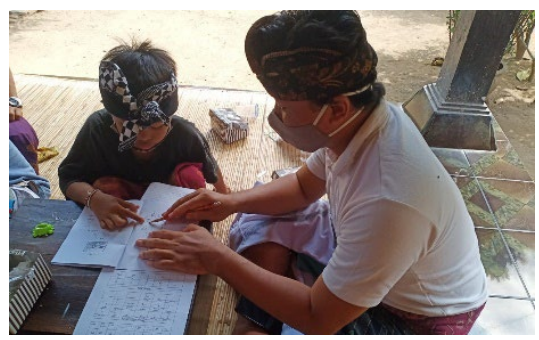

Gambar 8. Pendampingan cara membaca aksara Bali (Sumber: I Wayan Agus Gunada)

\section{Evaluasi Kegiatan Pelatihan dan Pembelajaran dasar-dasar aksara Bali}

Berdasarkan hasil pengamatan secara langsung dan berbincang kecil secara mendalam dengan peserta didik maka kegiatan pelatihan dan pembelajaran aksara Bali ini telah berjalan sesuai dengan harapan yang diinginkan. Namun dalam prosesnya terdapat beberapa hal yang menjadi kendala diantaranya 1) waktu yang singkat membuat proses pelatihan menjadi kurang maksimal, 2) situasi pandemi membuat proses interaksi antara pendidik dan peserta didik menjadi terbatas sehingga proses pembelajaran kurang efisien, 3) beberapa anak-anak cepat bosan karena materi aksara Bali yang cenderung dianggap terlalu rumit.

Dari beberapa kendala yang ada terdapat keberhasilan diantaranya 1) mayoritas anak-anak pada pasraman amerta sanjiwani sudah mengetahui bentuk-bentuk aksara Bali dan pengangge aksara, 2) Anak-anak sudah memahami dasar-dasar dalam menulis aksara Bali dengan ditunjukkan pembuatan kata-kata sederhana, 3) anak-anak sudah mampu untuk membaca kata-kata sederhana dalam aksara Bali.

\section{SIMPULAN DAN SARAN}

Situasi pandemi covid-19 yang tidak hanya melanda Indonesia namun seluruh dunia tentu tidak hanya berimbas pada perekonomian semata namun dalam berbagai faktor kehidupan manusia salah satunya pendidikan.
Ini juga yang menyebabkan proses pengabdian kepada masyarakat sebagai bentuk implementasi keilmuan pada tataran praksis dimasyarakat kurang maksimal begitu pula pelatihan dan pembelajaran yang dilakukan. Secara umum dapat digambarkan bahwa pelatihan dan pembelajaran aksara Bali pada anak-anak di Pasraman Amerta Sanjiwani sudah berjalan dengan baik, anak-anak sudah mampu memahami dasar-dasar aksara wreastra dan pengangge suara, serta sudah mampu menulis bentuk aksara dan menyusun serta membaca kata-kata sederhana dalam aksara Bali. Namun karena situasi pandemi membuat proses pelatihan dan pembelajaran kurang maksimal dikarenakan waktu yang terbatas serta proses interaksi yang dibatasi.

Kedepan diharapkan pandemi covid-19 ini segera berakhir sehingga proses pengabdian kepada masyarakat salah satunya pelatihan dan pembelajaran dasar-dasar aksara Bali ini dapat dilaksanakan lagi dengan waktu yang lebih panjang dan materi yang lebih luas lagi. Sehingga proses pelatihan dan pembelajaran aksara Bali dapat berjalan maksimal dan lestarinya keberadaan aksara Bali sebagai salah satu bentuk kebudayaan Nasional dilihat dari semakin banyaknya anakanak Hindu memahami secara teori pengetahuan dan keterampilan dalam membaca dan menulis aksara Bali sebagai bentuk penguatan pendidikan karakter religius melalui aksara Bali sebagai implementasi konsepsi nilai-nilai pendidikan agama Hindu.

\section{UCAPAN TERIMA KASIH}

Ucapan terima kasih sedalam-dalamnya disampaikan kepada Pemerintah Kabupaten Lombok Barat untuk pemberian izin pelaksanaan kegiatan Pengabdian Kepada Masyarakat dengan tetap memperhatikan pelaksanaan protokol kesehatan covid-19. Terima kasih pula disampaikan kepada Sekolah Tinggi Agama Hindu Negeri Gde Pudja Mataram karena telah memfasilitasi pelaksanaan pengabdian kepada masyarakat dan pengelola Pasaman Amerta Sanjiwani karena telah menerima kedatangan tim pengabdian kepada masyarakat Prodi Pendidikan Agama Hindu dan mendukung serta menunjang seluruh proses kegiatan yang direncanakan sehingga berjalan untuk dilaksanakan.

\section{DAFTAR RUJUKAN}

Agustino, L. (2020). Analisis Kebijakan Penanganan Wabah Covid-19: Pengalaman Indonesia Analysis Of Covid-19 Outbreak Handling Policy: The Experience Of Indonesia. Junal 
Borneo Administrator, 16(2), 253-270. https://doi.org/10.24258/jba.v16i2.685

Al-Muwattho, F. P., Aminuyati, \& Okianna. (2018). Pengaruh Pemberian Apersepsi Terhadap Kesiapan Belajar Siswa Pada Pelajaran Akuntansi Kelas Xi Sma Islamiyah Pontianak. Jurnal Pendidikan Dan Pembelajaran Khatulistiwa, 7(2), 1-10. Retrieved from https://jurnal.untan.ac.id/index.php/jpd $\mathrm{pb} /$ article/view/24076

Fatimah, \& Kartikasari, R. D. (2018). Strategi Belajar Dan Pembelajaran Dalam Meningkatkan Keterampilan Bahasa. Pena Literasi: Jurnal Pendidikan Bahasa Dan Sastra Indonesia, 1(2), 108-113.

https://doi.org/10.24853/pl.1.2.108-113

Giri, I. M. A. (2017). Pelestarian Bahasa, Aksara, dan Sastra Bali Melalui Pengoptimalan Tripusat Pendidikan. Purwadita, 1(1), 27-32. Retrieved from http://jurnal.stahnmpukuturan.ac.id/ind ex.php/Purwadita/article/view/6

Gunawan, I., \& Palupi, A. R. (2012). Taksonomi Bloom-Revisi Ranah Kognitif: Kerangka landasan Untuk Pembelajaran, Pengajaran, dan Penilaian. Premiere Educandum: Jurnal Pendidikan Dasar Dan Pembelajaran, 2(2), 98-117. https://doi.org/10.25273/pe.v2i02.50

Merthawan, G. (2017). Kajian Makna Dan Fungsi Pis Bolong Dalam Upacara Dewa Yajna Bagi Umat Hindu Di Kota Palu. Widya Genitri: Jurnal IImiah Pendidikan, Agama Dan Kebudayaan Hindu, 8(1), 21-28. https://doi.org/10.36417/widyagenitri.v $8 \mathrm{i} 1.215$

Nurhayati, H. (2018). Pendidikan Dan Pelatihan Sebagai Upaya Peningkatan Kinerja Pustakawan. Libria, 10(1), 95-115. Retrieved from https://www.jurnal.arraniry.ac.id/index.php/libria/article/view 13384

Pane, A., \& Darwis Dasopang, M. (2017). Belajar Dan Pembelajaran. FITRAH: Jurnal Kajian IImu-IImu Keislaman, 3(2), 333-352.

https://doi.org/10.24952/fitrah.v3i2.945

Parsua, G. R. (2018). Aksara Dalam Tubuh Manusia Menurut Lokalitas Hindu di Bali. Vidya Samhita Jurnal Penelitian, 4(1), 34-40. Retrieved from https://ejournal.indn.ac.id/index.php/vs/ article/view/697

Rai, I. B. (2013). Perkembangan Pasang Aksara Bali Dalam Upaya Pelestarian Budaya Bali. Jurnal IKA, 11(2), 16-26. https://doi.org/10.23887/ika.v11i2.1986

Randa, S., Lumbantoruan, J., \& Putra, I. E. D. (2018). Penggunaan Strategi Ekspositori Pada Pembelajaran Musik Tradisional Minangkabau Di Sma Negeri 3 Padang. Jurnal Sendratasik, 7(1), 1-6. Retrieved from http://ejournal.unp.ac.id/index.php/sen dratasik/article/view/100357

Setiyawan, P. A., Cahyawan W, A. A. K. A., \& Bayupati, I. P. A. (2014). Balinese Alphabet Sebagai Aplikasi Media Pembelajaran Aksara Bali Berbasis Android Mobile Platform. Merpati, 2(2), 226-237. Retrieved from https://ojs.unud.ac.id/index.php/merpat i/article/view/17890

Setyosari, P. (2020). Desain Pembelajaran (1st ed.; Bunga Sari Fatmawati, ed.). Jakarta: PT Bumi Aksara.

Sudiarta, I. G. (2016). Kemampuan Berbahasa Bali Pada Kalangan Remaja Di Desa Pakraman Peraupan Denpasar. Jurnal Penjaminan Mutu, 1(2), 59. https://doi.org/10.25078/jpm.v1i2.51

Sugiyono. (2020). Metode Penelitian Kualitatif Untuk Penelitian yang bersifat: Eksploratif, Enterpretif, Interaktif dan Konstruktif (1st ed.; S. Y. Suryandari, ed.). Bandung: ALFABETA.

Suwija, I. N. (2014). Pasang Aksara Bali (1st ed.; I. N. Suwija, ed.). Denpasar: Pelawa Sari.

Yusuf L.N, S., \& Sugandhi, N. M. (2013). Perkembangan Peserta Didik: Mata Kuliah Dasar Profesi (MKDP) Bagi Para Mahasiswa Calon Guru di Lembaga Pendidikan Tenaga Kependidikan (LPTK) (1st ed.). Jakarta: PT Raja Grafindo Persada. 